\title{
Litterfall Deposition and Decomposition in an Atlantic Forest in Southern Goiás
}

\author{
Suéllen do Vale Costa $^{1}$ (D), Marcos Antônio Pesquero ${ }^{1}$ (D), \\ Márcio Henrique Moraes Junqueira ${ }^{1}$
}

${ }^{1}$ Universidade Estadual de Goiás - UEG, Morrinhos/GO, Brasil

\begin{abstract}
Brazilian biomes have been severely threatened and their conservation depends on the knowledge of intrinsic ecological processes and correct phytophysiognomy identification of legal protection purposes. Litterfall deposition and decomposition patterns associated with taxonomic composition, climate, soil and relief can be considered important tools for vegetation typology. This study contributes to classifying the Natural Park of Morrinhos (Parque Natural de Morrinhos - PNM), a forest fragment in the southern region of Goiás, using litterfall deposition and decomposition rates. The results show intense litterfall deposition at the end of the dry period and rapid decomposition in the rainy season (62\%), requiring 494 days for total decomposition. The rapid litterfall decomposition rate $\left(\mathrm{k}=1.42\right.$ year-1 $\left.^{-1}\right)$, cumulative annual deposition of $6.43 \mathrm{Mg} \mathrm{ha}^{-1}$ and the taxonomic composition of the vegetation contribute to the classification of PNM as a Semi-deciduous Seasonal Forest.
\end{abstract}

Keywords: vegetation typology, Semi-deciduous Seasonal Forest, nutrient cycling. 


\section{INTRODUCTION}

The great extent and centralized geographic positioning of the Cerrado biome in Brazil resulted in transitional environments of this domain with Amazonian forests to the north and the Atlantic Forest to the south (Méio et al., 2003). However, Cerrado vegetation has been rapidly removed (Sano et al., 2010) to meet the expansion of the agricultural frontier within the country, as initiated by President Vargas government in the 1930s known as 'March to the West' (Marcha para o Oeste) (Pádua, 2007). In the southern region of Goiás and concomitant with Cerrado deforestation, there are only $2.6 \%$ of the 1,190,184 ha of Atlantic Forest originally dispersed throughout 26 municipalities, including the municipality of Morrinhos (Fundação SOS Mata Atlântica \& INPE, 2013, 2015). Scarano (2014) addresses the scientific, environmental, economic and social relevance of Cerrado and discusses conservation strategies for this biome.

To do so, it is necessary to classify the vegetation to be conserved and/or restored as protected areas, which is carried out through technical and scientific studies. The predominant tropical forest formations in Brazil are classified according to physiognomic and ecological criteria based on four basic interrelated factors: rainfall, altitude, temperature and soil (IBGE, 2012). For example, the duration of the dry period classifies forests into Ombrophilous and Seasonal (Projeto RADAMBRASIL, 1983). Thus, two parameters directly related to climate are considered as classification criteria of the different forest formations: i) production of dead organic matter (litterfall), mainly represented by leaves falling off trees/plants; and ii) speed with which nutrients that compose litterfall become available to plants through the mineralization process that occurs during litterfall decomposition (Olson, 1963; Bray \& Gorham, 1964).

Decomposers play a key ecological role within ecosystems, recycling considerable part of the energy and nutrients present in dead plant matter, which was not used by herbivores, and soil fauna and climate are important factors regulating this microbial activity (Lavelle et al., 1993; Pereira et al., 2013). Wieder \& Wright (1995) found that the litterfall decomposition rate was accelerated in a Tropical Forest area in "Barro Colorado" through irrigation during the dry period (four months) over five years; however, during the autumn period, the number of fallen leaves was not affected by irrigation, evidencing the evolutionary character of dehiscence to climatic variations. Thus, litterfall production and decomposition can be considered important tools for the description of phytophysiognomies. The aim of this study was to quantify litterfall production and decomposition rates in the Natural Park of Morrinhos (Parque Natural de Morrinhos - PNM), one of the few Atlantic Forest remnants in the state of Goiás, and the only conservation unit recognized in the municipality.

\section{MATERIAL AND METHODS}

\subsection{Study site}

$P N M$ is located at north of the urban area of Morrinhos in Goiás (17\%43'35"S and 4907'52”W), $790 \mathrm{~m}$ above sea level and corresponds to an area of approximately 104 ha. It was created with the main function of protecting the water spring of the "Maria Lucinda" stream. The natural park is composed of perennial and deciduous plant species, with canopy measuring up to $30 \mathrm{~m}$ in height. Popular and scientific names of tree species are provided by the $P N M$ administration through signage set up along visitation trails. According to a systematized floristic survey conducted in 2013, 51 species distributed into 40 genera and 26 families were identified, with Siparuna guianensis Aublet, Styrax camporum Pohl, Piper aduncun L., Ocotea aciphylla (Nees \& Mart) Mez, Tapirira obtusa (Benth.) D.J.Mitch., Miconia nervosa (Sm.) Triana, Inga marginata Willd, Matayba guianensis Aubl., Casearia sylvestres Swand Copafeira langsdorffi Desf (Junqueira MHM, unpublished data) being the most abundant. The climate of the region is Aw according to the Köppen classification, being seasonal and characterized by cold period from May to August $\left(20.85 \pm 1.10^{\circ} \mathrm{C}\right)$, and warm period from September to April $\left(24.33 \pm 0.81^{\circ} \mathrm{C}\right)$. Rains are intense from November to March $(241.07 \pm 32.50 \mathrm{~mm})$, reduced from May to August $(9.57 \pm 1.44 \mathrm{~mm})$, and intermediate in April, September and October (77.34 $\pm 13.46 \mathrm{~mm}$ ) (Pesquero et al., 2012).

\subsection{Data collection}

Total litterfall production (leaves, flowers, fruits and small branches) was monthly estimated from October 2011 to September 2012 using 30 plastic collectors $\left(1 \mathrm{~m}^{2}\right)$ adapted with a drain to avoid rainwater accumulation, 
elevated $10 \mathrm{~cm}$ from the ground and arranged in-line within PNM, with a distance of at least $50 \mathrm{~m}$ from each other. All plant material monthly intercepted by collectors was packed in 100-liter plastic bags and kept under refrigeration $\left(10-15^{\circ} \mathrm{C}\right)$ until drying in oven at $70^{\circ} \mathrm{C}$ for $48 \mathrm{~h}$. After drying, leaves were weighed using digital electronic scale $(0.01 \mathrm{~g}$ accuracy).The rest of the material (small branches, flowers and fruits) was weighed together to verify the proportion of leaves in relation to the total deposited material.

Leaf litterfall decomposition was monthly estimated for one year (October 2011 to September 2012) through the use of 360 nylon canvas bags ( $30 \times 25 \mathrm{~cm}, 2 \mathrm{~mm}$ mesh) numbered according to leaf dry biomass, which varied from 25 to $47 \mathrm{~g}(26.73 \pm 3.46 \mathrm{~g})$, distributed in lots of 12 units located close to the 30 litterfall collectors. Dried leaves placed inside the nylon bags were randomly collected from the upper layer of litterfall collectors arranged above the ground in the PNM in September 2011 , and all material was dried in oven at $70^{\circ} \mathrm{C}$ and weighed on a digital electronic scale until reaching constant mass ( $0.01 \mathrm{~g}$ accuracy).

\subsection{Data analysis}

The mean monthly litterfall deposition was compared according to the annual deposition seasonality using Student $\mathrm{t}$-test for independent sampling. The annual deposition was compared to results obtained in SSF, SDF and OF (Semi-deciduous Seasonal Forest; Seasonal Deciduous Forest; and Ombrophilous Forest, respectively) studies published in scientific journals in the last 10 years (Scielo and Google Scholar databases); this period was expanded in the case of low $\mathrm{n}$ sample by means of the Student $\mathrm{t}$-test for one sample. This test compares the mean values of data obtained in literature with value obtained in the study area (PNM), and is performed by estimating the variance in $P N M$ by the variance of data obtained in literature. This procedure is suitable for small-sized samples ( $\mathrm{n} \leq 30$ ) (Ayres et al., 2007).

Litterfall decomposition rates $(\mathrm{k})$ were monthly calculated according to Equations 1 and 2 (Olson, 1963):

$$
\begin{aligned}
& k=-\ln \left(1-k^{\prime}\right) \\
& k^{\prime}=X_{t} / X_{0}
\end{aligned}
$$

Where $X_{t}$ is the amount of material decomposed in time interval $t$, and $X_{0}$ is the initial amount of dead organic matter.
Climatic data for precipitation, temperature and air humidity were obtained from the Climatological Station of the State University of Goiás - Campus Morrinhos, in order to verify correlation patterns (Spearman's non-parametric R analysis) with biological deposition and decomposition variables. Simple linear regression analysis was used to estimate loss of litterfall leaf mass over time. Analyses were performed using the BioEstat 5 software (Ayres et al., 2007). The mean values of variables analyzed are accompanied by their respective standard deviations. Data were analyzed through non-parametric tests when they did not meet normality and homoscedasticity.

\section{RESULTS AND DISCUSSION}

Litterfall deposition in PNM occurred according to a seasonal pattern with the highest average fall in the period from July to October (peaking in September) compared to the average decomposition in the period from November to June $\left(93.82 \pm 44.13 \mathrm{~g} \mathrm{~m}^{-2}\right.$ vs. $33.26 \pm 16.71 \mathrm{~g} \mathrm{~m}^{-2}, \mathrm{t}=19.76, \mathrm{df}=358, \mathrm{p}<0.0001$, Figure 1). This period of greatest leaf fall corresponds to the dry and cold season of the region (Figure 2) (Pesquero et al., 2012). In fact, dehiscence presented significant negative correlation values with variables temperature, precipitation and air humidity (Table 1). Several studies have demonstrated similar seasonal dehiscence pattern in seasonal forests (Table 2). Leaves accounted for most of the material collected throughout the year $(66 \pm 11 \%, \mathrm{n}=12)$, and within the range expected (60-80\%) for Atlantic Forest biome vegetation types (Vieira et al., 2016).

The total litterfall deposited throughout the year in PNM (6.43 $\left.\mathrm{Mg} \mathrm{ha}^{-1}\right)$ did not differ from the average values for seasonal forests reported in literature $\left(\mathrm{SSF}=8.54 \pm 2.03 \mathrm{Mg} \mathrm{ha}^{-1}, \mathrm{n}=6, \mathrm{t}=2.54, \mathrm{p}=0.052\right.$ and $\mathrm{SDF}=8.03 \pm 1.71 \mathrm{Mg} \mathrm{ha}^{-1}, \mathrm{n}=5, \mathrm{t}=2.09, \mathrm{p}=0.10$, respectively, Table 2). However, litterfall deposition in $P N M$ was lower than the average values observed in literature for Ombrophilous Forest $\left(8.31 \pm 1.83 \mathrm{Mg} \mathrm{ha}^{-1}\right.$, $\mathrm{n}=11, \mathrm{t}=3.42, \mathrm{p}=0.006$, Table 2). Precipitation is considered the main factor that can explain differences in litterfall production in tropical biomes, in which higher rates were found for humid environments (Tonin et al., 2017). In fact, elevated temperatures (average of $25^{\circ} \mathrm{C}$ ) and higher precipitation ( $<60$ days of drought) are climatic factors associated with Dense Ombrophilous Forests (IBGE, 2012). 


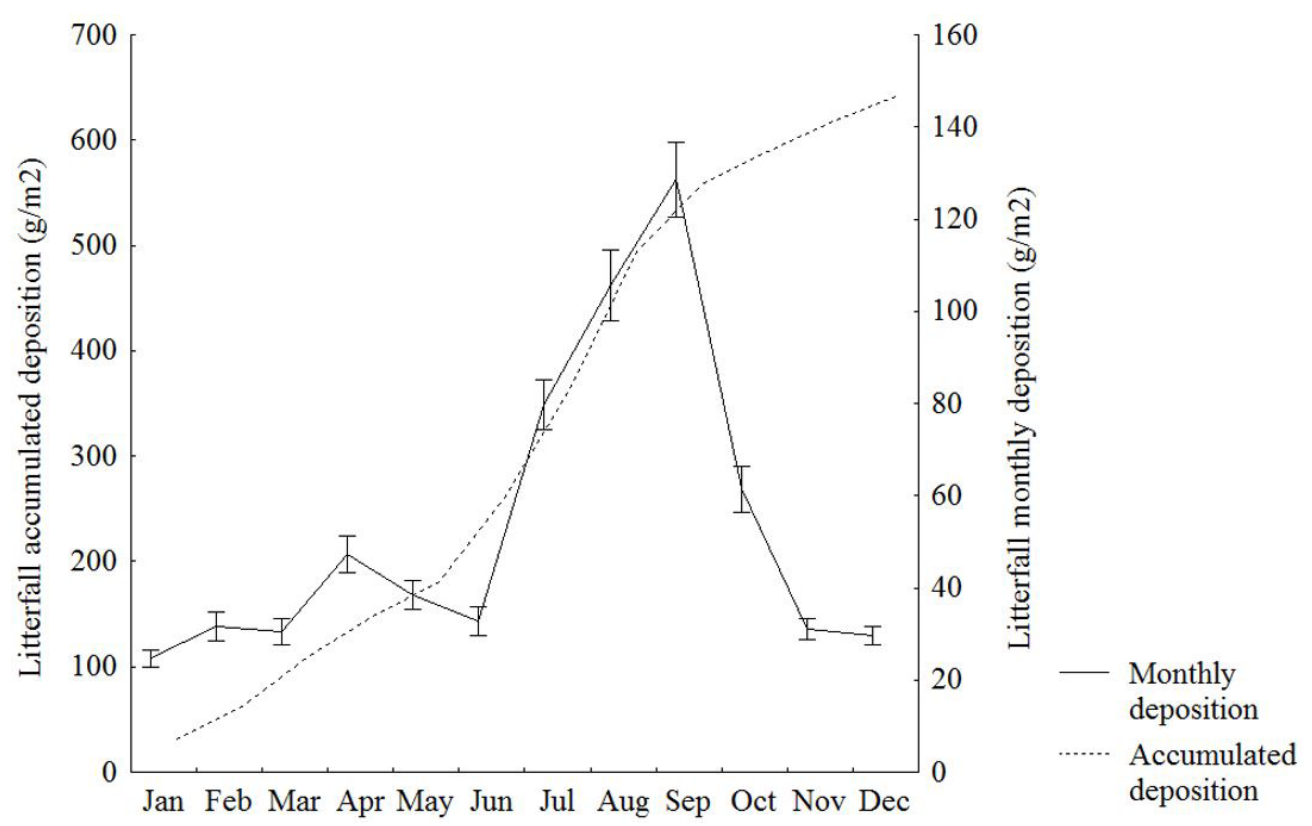

Figure 1. Monthly and accumulated litterfall deposition $\left(\mathrm{g} \cdot \mathrm{m}^{-2}\right)$ at the Natural Park of Morrinhos (PNM), Morrinhos (GO).

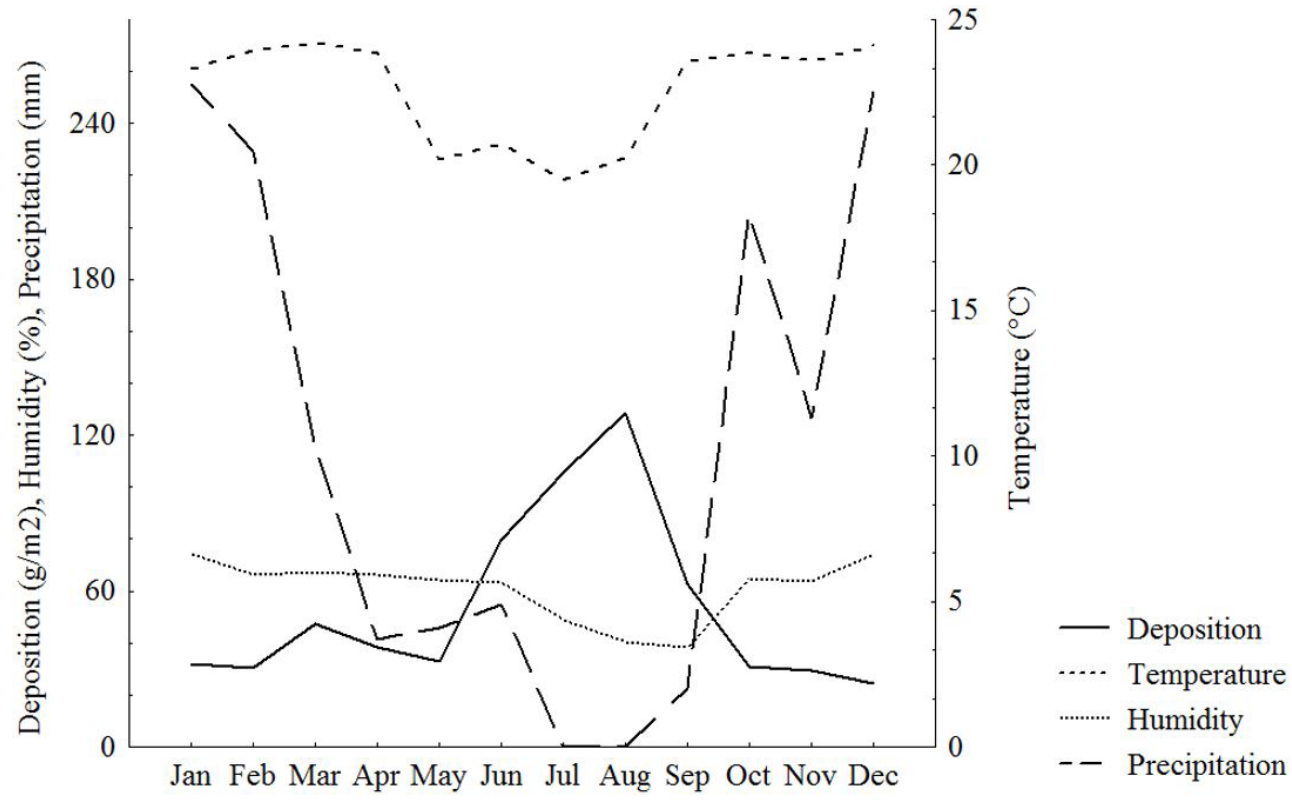

Figure 2. Annual variation of climatic parameters and litterfall deposition at the Natural Park of Morrinhos (PNM), Morrinhos (GO).

Table 1. Relationship between litterfall deposition and climatic variables at the Natural Park of Morrinhos (PNM), Morrinhos (GO).

\begin{tabular}{llcrr}
\multicolumn{1}{c}{ Interaction } & $\mathbf{N}$ & R Spearman & $\mathbf{t}(\mathbf{n}-\mathbf{2})$ & $\mathbf{p}$ \\
\hline Deposition x Temperature & 12 & -0.60 & -2.38 & 0.038 \\
\hline Deposition x Humidity & 12 & -0.65 & -2.71 & 0.022 \\
\hline Deposition x Precipitation & 12 & -0.83 & -4.71 & 0.001 \\
\hline
\end{tabular}


Table 2. Annual litterfall deposition rates in seasonal and humid forests of the Atlantic Forest biome.

\begin{tabular}{|c|c|c|}
\hline Type of forest & $\frac{\text { Deposition }}{\left(\mathrm{Mg} \mathrm{ha}^{-1}\right)}$ & Source \\
\hline PNM & 6.43 & Present study \\
\hline \multirow{6}{*}{ Semi-deciduous Seasonal Forest } & 9.30 & Godinho et al. (2013) \\
\hline & 6.10 & Bauer et al. (2017) \\
\hline & 8.21 & Pimenta et al. (2011) \\
\hline & 8.82 & Pinto et al. (2009) \\
\hline & 6.90 & Scoriza \& Piña-Rodrigues (2014) \\
\hline & 11.90 & Toscan et al. (2017) \\
\hline \multirow{5}{*}{ Seasonal Deciduous Forest } & 7.76 & Cunha et al. (1993) \\
\hline & 10.17 & Machado et al. (2008) \\
\hline & 9.20 & König et al. (2002) \\
\hline & 5.85 & Marafiga et al. (2012) \\
\hline & 7.14 & Turchetto \& Fortes (2014) \\
\hline \multirow{11}{*}{ Ombrophilous Forest } & 6.10 & Antoneli \& Thomaz (2012) \\
\hline & 7.99 & Caldeira et al. (2007) \\
\hline & 7.72 & Cunha \& Gama-Rodrigues (2014) \\
\hline & 10.07 & Espig et al. (2009) \\
\hline & 6.75 & Inkotte et al. (2015) \\
\hline & 8.35 & Longhi et al. (2011) \\
\hline & 8.90 & Portela \& Santos (2007) \\
\hline & 6.40 & Scheer et al. (2011) \\
\hline & 12.62 & Schessl et al. (2008) \\
\hline & 8.44 & Sloboda et al. (2017) \\
\hline & 6.81 & Vidal et al. (2007) \\
\hline
\end{tabular}

Oliveira \& Fontes (2000) point out several factors associated with the floristic composition of the Atlantic Forest such as rainfall, temperature, latitude, altitude, and continentality, and also emphasize its extent in its definition as a biome. Another factor related to the vegetation type of a region is the presence of limestone lithology, which is considered an important feature in identifying SDF (Projeto RADAMBRASIL, 1983). Despite the lack of systematized studies, the PNM soil does not present thin cover or low representativeness of surface drainage, which are characteristics present in calcareous terrain. Although deciduous species such as Copafeira langsdorffi, Hymenaea courbaril L. and Astronium fraxinifolium Schott are found in PNM, together they represent only $6 \%$ of the relative density (Junqueira MHM, unpublished data).

The warm and rainy period of the region from October to March (Pesquero et al., 2012) favored the action of decomposing organisms, which consumed $62 \%$ of leaves inside the nylon bags, while only $12 \%$ were decomposed in the remaining dry months (Figure 3 ). Thus, $74 \%$ of the leaf biomass was decomposed after the period of one year, in which regression analysis predicted approximately 494 days for its total renewal [leaf biomass $(\mathrm{g})=19.271-(0.039$ * number of days $)$, adjusted $\mathrm{R}^{2}=0.89, \mathrm{~F}(1,10)=91.031, \mathrm{p}<0.0001$, Table 3, Figure 4]. Litterfall renewal time in PNM is comprised within values observed by Vital et al. (2004) and Pinto et al. (2009) for SSF; however, it is much shorter than the estimated time of up to 983 days for the disappearance of $95 \%$ litterfall in SDF (Cunha et al., 1993, Turchetto \& Fortes, 2014).

Results that reinforce the similarity between PNM and SSF were obtained through the litterfall decomposition rate $(\mathrm{k})$, which increased gradually over time until reaching the value of 1.42 in August (Figure 5). Values of $\mathrm{k}>1$ show rapid cycling of litterfall nutrients, typical of tropical climate biomes (Olson, 1963). The $\mathrm{k}$ value of $P N M$ did not differ from the mean $\mathrm{k}$ values observed for SSF reported in literature $(1.48 \pm 0.51, \mathrm{t}=0.29, \mathrm{p}=0.78, \mathrm{n}=7$, Table 4$)$. Although the few studies available in literature make comparison impossible, our results suggest higher decomposition rate in SDF and lower in OF (Table 4). 


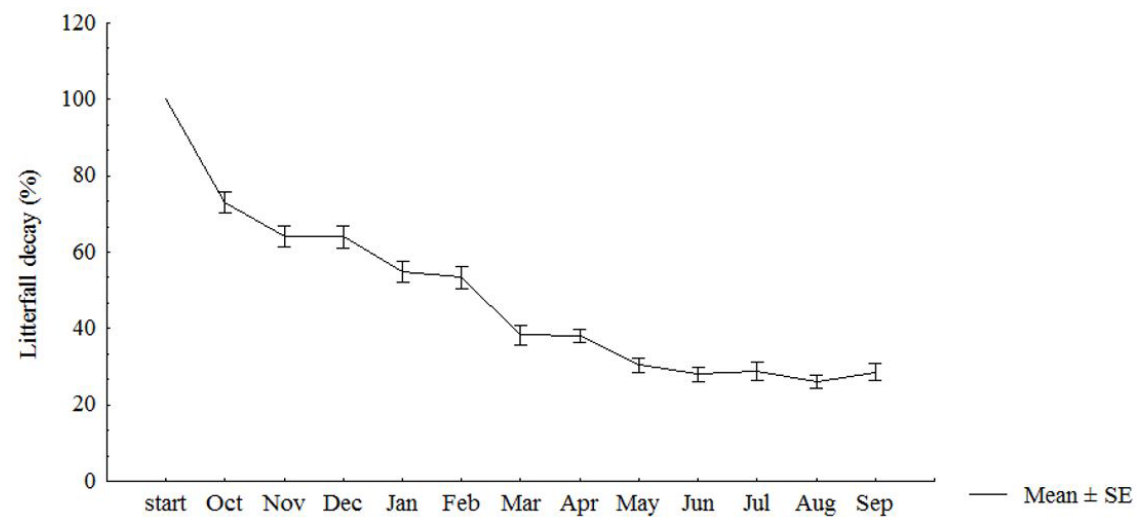

Figure 3. Leaf litterfall decomposition at the Natural Park of Morrinhos (PNM), Morrinhos (GO).

Table 3. Regression parameters between leaf biomass losses and the elapsed time at the Natural Park of Morrinhos $(P N M)$, Morrinhos (GO).

\begin{tabular}{|c|c|c|c|c|c|c|}
\hline & \multirow[b]{2}{*}{ BETA } & BETA & \multirow[b]{2}{*}{ B } & B & \multirow[b]{2}{*}{$\mathbf{t}(\mathbf{1 0})$} & \multirow[b]{2}{*}{$\mathbf{p}$} \\
\hline & & $\begin{array}{l}\text { Standard } \\
\text { error }\end{array}$ & & $\begin{array}{l}\text { Standard } \\
\text { error }\end{array}$ & & \\
\hline Intercept & & & 19.271 & 0.903 & 21.357 & 0.0001 \\
\hline Days elapsed & -0.949 & 0.099 & -0.039 & 0.004 & -9.54 & 0.0002 \\
\hline
\end{tabular}

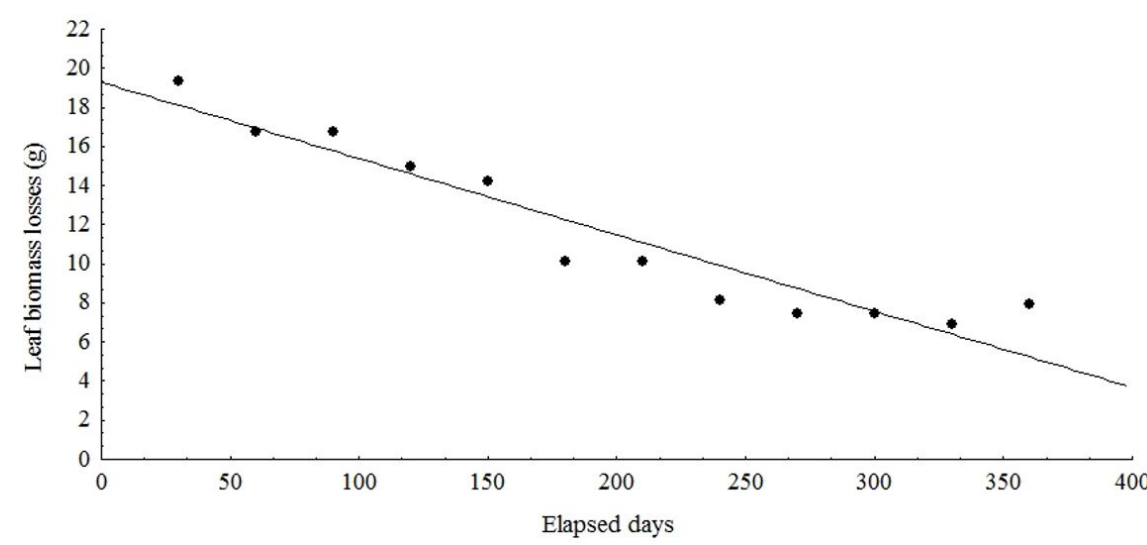

Figure 4. Decomposition rate (litterfall collectors) as a function of the time elapsed in days in the Natural Park of Morrinhos (PNM), Morrinhos (GO).

Table 4. Annual litterfall decomposition rates $(\mathrm{k})$ in seasonal and humid forests of the Atlantic Forest biome.

\begin{tabular}{|lll|}
\hline \multicolumn{1}{c}{ Type of forest } & Decay $(\mathbf{k})$ & \multicolumn{1}{c|}{ Source } \\
\hline PNM & 1.42 & Present study \\
& 0.99 & Bauer et al. (2017) \\
& 2.45 & Pimenta et al. (2011) \\
\hline Semi-deciduous Seasonal Forest & 1.26 & Pinto et al. (2009) \\
& 1.30 & Morellato (1992) \\
& 1.60 & Morellato (1992) \\
\hline Seasonal Deciduous Forest & 1.71 & Vital et al. (2004) \\
\hline \multirow{2}{*}{ Ombrophilous Forest } & 1.02 & Schlittler et al. (1993) \\
\hline
\end{tabular}




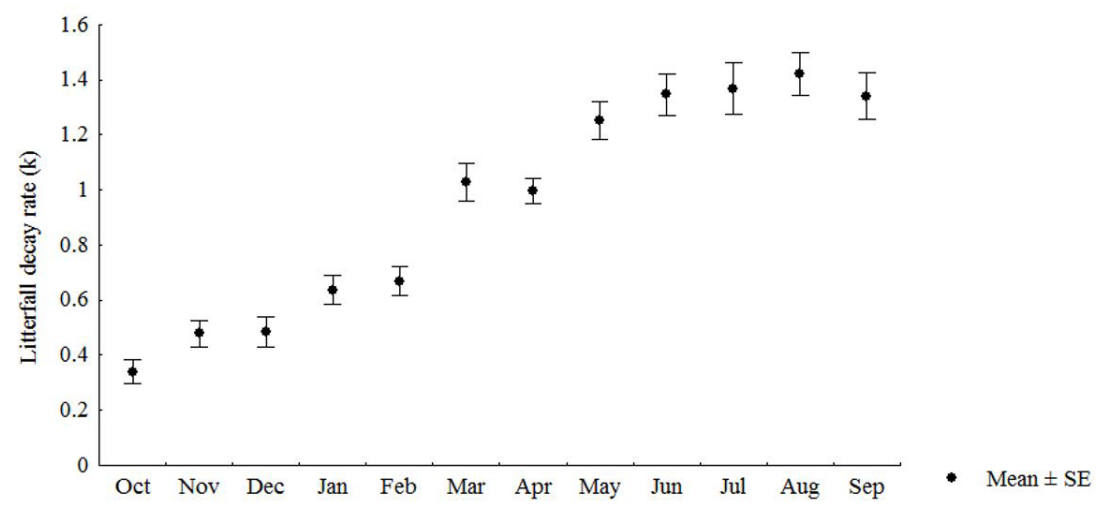

Figure 5. Average litterfall decomposition rate (k) at the Natural Park of Morrinhos (PNM), Morrinhos (GO).

\section{CONCLUSIONS}

The dynamics of litterfall deposition and decomposition in $P N M$ shows rapid incorporation of nutrients into the soil, typical of Tropical Forest. The values of these parameters associated with the composition of perennial dominant plant species identify this vegetation fragment as a Semi-deciduous Seasonal Forest. However, further studies should be carried out in the Atlantic Forest (mainly deciduous seasonal rainforest and ombrophilous forest), considering decomposition factor $\mathrm{k}$ as an important integrating component for nutrient cycling dynamics and descriptor of the forest typology.

\section{ACKNOWLEDGEMENTS}

We thank Loane Cristina de Souza and the Environment Superintendence of Morrinhos for their support for data collection in the Morrinhos Natural Park. An anonymous reviewer of the manuscript provided a number of helpful suggestions.

\section{SUBMISSION STATUS}

Received: 6 july, 2017

Accepted: 14 feb., 2018

\section{CORRESPONDENCE TO}

\section{Marcos Antônio Pesquero}

Programa de Pós-graduação em Ambiente e Sociedade, Universidade Estadual de Goiás - UEG, Rua 14, 625, CEP 75650-000, Morrinhos, GO, Brasil

e-mail: mapesq@ueg.br

\section{FINANCIAL SUPPORT}

Programa de Concessão de Bolsa de Incentivo ao Pesquisador (PROBIP-UEG); Iniciação Científica e Tecnológica (IC\&T-UEG); Capes/Fapeg (Grant/Award Number: 1656/2016)

\section{REFERENCES}

Antoneli V, Thomaz EL. Produção de serrapilheira em um fragmento de floresta ombrófila mista com sistema de faxinal. Sociedade \& Natureza 2012; 24(3): 489-504. http://dx.doi.org/10.1590/S1982-45132012000300009.

Ayres M, Ayres M Jr, Ayres DL, Santos AAS. BioEstat: aplicações estatísticas nas áreas das ciências bio-médicas. 5. ed. Belém: Sociedade Civil Mamirauá; 2007.

Bauer D, Führ CS, Schmitt JL. Dinâmica do acúmulo e decomposição de serapilheira em Floresta Estacional semidecidual subtropical. Pesquisas Botânica 2017; 70: 1-11.

Bray JR, Gorham E. Litter production in forests of the world. Advances in Ecological Research 1964; 2: 101-157. http://dx.doi.org/10.1016/S0065-2504(08)60331-1.

Caldeira MVW, Marques R, Soares RV, Balbinot R. Quantificação de serapilheira e de nutrientes - Floresta Ombrófila Mista Montana - Paraná. Revista Acadêmica 2007; 5(2): 101-116. http://dx.doi.org/10.7213/cienciaanimal. v5i2.9720.

Cunha GC, Grendene LA, Durlo MA, Bressan DA. Dinâmica nutricional em floresta estacional decidual com ênfase aos minerais provenientes da deposição da serapilheira. Ciência Florestal 1993; 3(1): 35-64. http:// dx.doi.org/10.5902/19805098284.

Cunha GM, Gama-Rodrigues AC. Does nutrient cycling differ between fragments of Atlantic Forest with distinct structural aspects? A case study in the state of Rio de Janeiro, Brazil. Acta Botanica Brasílica 2014; 28(4): 609616. http://dx.doi.org/10.1590/0102-33062014abb3525. 
Espig SA, Freire FJ, Marangon LC, Ferreira RLC, Freire MBGS, Espig DB. Sazonalidade, composição e aporte de nutrientes da serapilheira em fragmento de Mata Atlântica. Revista Árvore 2009; 33(5): 949-956. http:// dx.doi.org/10.1590/S0100-67622009000500017.

Fundação SOS Mata Atlântica. Instituto Nacional de Pesquisas Espaciais - INPE. Atlas dos municípios da Mata Atlântica: ano base 2013. São Paulo: Fundação SOS Mata Atlântica; 2013 [cited 2017 Apr 20]. Available from: http:// mapas.sosma.org.br/site_media/download/estatisticas/ Atlas_municipios2014_anobase2013.pdf

Fundação SOS Mata Atlântica. Instituto Nacional de Pesquisas Espaciais - INPE. Atlas dos remanescentes florestais da Mata Atlântica: período 2015-2016. São Paulo: Fundação SOS Mata Atlântica; 2015 [cited 2017 Apr 19]. Available from: https://www.sosma.org.br/link/Atlas_ Mata_Atlantica_2015-2016_relatorio_tecnico_2017.pdf

Godinho TO, Caldeira MVW, Caliman JP, Prezotti LC, Watzlawick LF, Azevedo HCA et al. Biomassa, macronutrientes e carbono Orgânico na serapilheira depositada em trecho de floresta Estacional Semidecidual Submontana, ES. Scientia Forestalis 2013; 41(97): 131-144.

Golley FB, McGinnis JT, Clements RG. Ciclagem de minerais em um ecossistema de floresta tropical úmida. São Paulo: Pedagógica e Universitária; 1978.

Inkotte J, Mafra AL, D’Ângelo Rios P, Baretta D, Vieira HC. Deposição de serapilheira em reflorestamentos de eucalipto e florestas nativas nas regiões Planalto e Oeste do Estado de Santa Catarina. Scientia Forestalis 2015; 43(106): 261-270.

Instituto Brasileiro de Geografia e Estatística - IBGE. Manual técnico da vegetação brasileira. 2. ed. Rio de Janeiro: IBGE; 2012.

König FG, Schumacher MV, Brun EJ, Seling I. Avaliação da sazonalidade da produção de serapilheira numa Floresta Estacional Decidual no município de Santa Maria-RS. Revista Árvore 2002; 26(4): 429-435. http:// dx.doi.org/10.1590/S0100-67622002000400005.

Lavelle P, Blanchart E, Martin A, Martin S, Spain A, Toutan $\mathrm{F}$ et al. hierarchical model for decomposition in terrestrial ecosystems: Application to soils of the humid tropics. Biotropica 1993; 25(2): 130-150. http://dx.doi. org/10.2307/2389178.

Longhi RV, Longhi SJ, Chami LB, Watzlawick LF, Ebling AA. Produção de serapilheira e retorno de macronutrientes em três grupos florísticos de uma Floresta Ombrófila Mista, RS. Ciência Florestal 2011; 21(4): 699-710. http:// dx.doi.org/10.5902/198050984514.

Machado MR, Piña Rodrigues FCM, Pereira MG. Produção de serapilheira como bioindicador de recuperação em plantio adensado de revegetação. Revista Árvore 2008; 32(1): 143-151. http://dx.doi.org/10.1590/S010067622008000100016 .
Marafiga JS, Viera M, Szymczak DA, Schumacher MV, Trüby P. Deposição de nutrientes pela serapilheira em um fragmento de Floresta Estacional Decidual no Rio Grande do Sul. Revista Ceres 2012; 59(6): 765-771. http://dx.doi. org/10.1590/S0034-737X2012000600005.

Méio BB, Freitas CV, Jatobá L, Silva MEF, Ribeiro JF, Henriques RPB. Influência da flora das florestas Amazônica e Atlântica na vegetação do cerrado sensu stricto. Brazilian Journal of Botany 2003; 26(4): 437-444. http://dx.doi. org/10.1590/S0100-84042003000400002.

Morellato LPC. Nutrient cycling in two south-east Brazilian forests. I Litterfall and litter standing crop. Journal of Tropical Ecology 1992; 8(2): 205-215. http:// dx.doi.org/10.1017/S0266467400006362.

Oliveira AT Fo, Fontes MAL. Patterns of floristic differentiation among Atlantic Forests in Southeastern Brazil and the influence of climate. Biotropica 2000; 32(4b): 793-810. http://dx.doi.org/10.1111/j.1744-7429.2000.tb00619.x.

Olson JS. Energy storage and the balance of producers and decomposers in ecological systems. Ecology 1963; 42(2): 322-331. http://dx.doi.org/10.2307/1932179.

Pádua AAS. A Sobrevida da Marcha para o Oeste. Estudos 2007; 34(7/8): 623-643.

Pereira GHA, Pereira MG, Anjos LHC, Amorim TA, Menezes CEG. Decomposição da serrapilheira, diversidade e funcionalidade de invertebrados do solo em um fragmento de Floresta Atlântica. Bioscience Journal 2013; 29(5): 1317-1327.

Pesquero MA, Chaves JC Fo, Junqueira DI. Desafios da sociedade na produção de alimento. In: Silva MV, Pesquero MA, editores. Caminhos interdisciplinares pelo ambiente, história e ensino: o sul goiano no contexto. Uberlândia: Assis; 2012.

Pimenta JA, Rossi LB, Torezan JMD, Cavalheiro AL, Bianchini E. Produção de serapilheira e ciclagem de nutrientes de um reflorestamento e de uma floresta estacional semidecidual no sul do Brasil. Acta Botanica Brasílica 2011; 25(1): 53-57. http://dx.doi.org/10.1590/ S0102-33062011000100008.

Pinto SIC, Martins SV, Barros NF, Dias HCT. Ciclagem de nutrientes em dois trechos de floresta estacional semidecidual na reserva florestal Mata do Paraíso em Viçosa, MG, Brasil. Revista Árvore 2009; 33(4): 653-663. http://dx.doi.org/10.1590/S0100-67622009000400008.

Portela RCQ, Santos FAM. Produção e espessura da serapilheira na borda e interior de fragmentos florestais de Mata Atlântica de diferentes tamanhos. Revista Brasileira de Botanica. Brazilian Journal of Botany 2007; 30(2): 271280. http://dx.doi.org/10.1590/S0100-84042007000200011.

Projeto RADAMBRASIL. Folhas SF 23/24, Rio de Janeiro/ Vitória: geologia, geomorfologia, pedologia, vegetação e uso potencial da terra. Vol. 32. Rio de Janeiro: Projeto RADAMBRASIL; 1983. 
Sano EE, Rosa R, Brito JLS, Ferreira LG. Land cover mapping of the tropical savana region in Brazil. Environmental Monitoring and Assessment 2010; 166(1-4): 113-124. http:// dx.doi.org/10.1007/s10661-009-0988-4. PMid:19504057.

Scarano FR. Mata Atlântica: uma história do futuro. Rio de Janeiro: Edições de Janeiro, Conservação Internacional; 2014.

Scheer MB, Gatti G, Wisniewski C. Nutrient fluxes in litterfall of a secondary successional alluvial rain forest in Southern Brazil. Revista de Biología Tropical 2011; 59(4): 1869-1882. PMid:22208099.

Schessl M, Silva WL, Gottsberger G. Effects of fragmentation on forest structure and litter dynamics in Atlantic rainforest in Pernambuco, Brazil. Flora 2008; 203(3): 215-228. http:// dx.doi.org/10.1016/j.flora.2007.03.004.

Schlittler FHM, De Marinis G, César O. Decomposição da serapilheira produzida na floresta do Morro do Diabo (região do Pontal do Paranapanema, Estado de São Paulo). Naturalia (São José do Rio Preto) 1993; 18: 149-156.

Scoriza RN, Piña-Rodrigues FCM. Influência da precipitação e temperatura do ar na produção de serapilheira em trecho de Floresta Estacional em Sorocaba, SP. Floresta 2014; 44(4): 687-696. http://dx.doi.org/10.5380/rf.v44i4.34274.

Sloboda B, Marques R, Bianchin J, Blum H, Donha C, Silveira $\mathrm{F}$ et al. Litterfall and nutrient dynamics in a mature Atlantic Rainforest in Brazil. Floresta e Ambiente 2017; 24(0): e20160339. http://dx.doi.org/10.1590/21798087.033916 .

Tonin AM, Gonçalves JF Jr, Bambi P, Couceiro SRM, Feitoza LAM, Fontana LE, et al. Plant litter dynamics in the forest stream interface: precipitation is a major control across tropical biomes. Scientific Reports 2017; 7: 1-14. http://dx.doi.org/10.1038/s41598-017-10576-8.

Toscan MAG, Guimarães ATB, Temponi LG. Caracterização da produção de serapilheira e da chuva de sementes em uma reserva de Floresta Estacional Semidecidual, Paraná. Ciência Florestal 2017; 27(2): 415-427. http://dx.doi. org/10.5902/1980509827725.

Turchetto F, Fortes FO. Aporte e decomposição de serapilheira em Floresta Estacional Decidual na região do Alto Uruguai, RS. Pesquisa Florestal Brasileira 2014; 34(80): 391-397. http://dx.doi.org/10.4336/2014.pfb.34.80.735.

Vidal MM, Pivello VR, Meirelles ST, Metzger JP. Produção de serapilheira em floresta Atlântica secundária numa paisagem fragmentada (Ibiúna, SP): importância da borda e tamanho dos fragmentos. Revista Brasileira de Botanica. Brazilian Journal of Botany 2007; 30(3): 521-532. http:// dx.doi.org/10.1590/S0100-84042007000300016.

Vieira M, Caldeira MVW, Rovani FFM, Castro KC. Ecological and environmental aspects of nutrient cycling in the Atlantic Forest, Brazil. In: Blanco JA, Chang SC, Lo $\mathrm{YH}$, editors. Tropical forests - the challenges of maintaining ecosystem services while managing the landscape. Croatia: INTECH; 2016. http://dx.doi.org/10.5772/64188.

Vital ART, Guerrini IA, Franken WK, Fonseca RCB. Produção de serapilheira e ciclagem de nutrientes de uma Floresta Estacional Semidecidual em zona ripária. Revista Árvore 2004; 28(6): 793-800. http://dx.doi.org/10.1590/ S0100-67622004000600004.

Wieder RK, Wright SJ. Tropical forest litter dynamics and dry season irrigation on Barro Colorado Island, Panama. Ecology 1995; 76(6): 1971-1979. http://dx.doi. org/10.2307/1940727. 